\title{
Development of a high temperature microbial fermentation process for butanol
}

Jeffery D. St. Jeor, David W. Reed, Dayna L. Daubaras, Vicki S. Thompson

August 2015

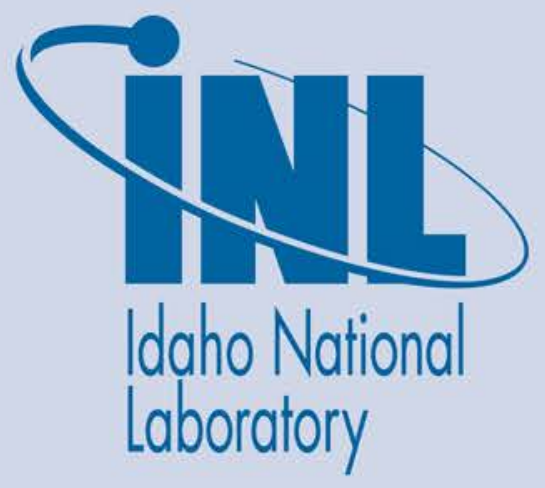

The INL is a U.S. Department of Energy National Laboratory operated by Battelle Energy Alliance 
INL/EXT-15-35964

\title{
Development of a high temperature microbial fermentation process for butanol
}

\author{
Jeffery D. St. Jeor ${ }^{1}$, David W. Reed ${ }^{2}$, \\ Dayna L. Daubaras ${ }^{2}$, Vicki S. Thompson ${ }^{2}$
}

August 2015

\begin{abstract}
Idaho National Laboratory
Idaho Falls, Idaho 83415
\end{abstract}

http://www.inl.gov 


\section{Development of a high temperature microbial fermentation process for butanol}

Jeffery D. St. Jeor, David W. Reed, Dayna L. Daubaras, Vicki S. Thompson

\section{Abstract}

Transforming renewable biomass into cost-competitive high-performance biofuels and bioproducts is key to the U.S. future energy and chemical needs. Butanol production by microbial fermentation for chemical conversion to polyolefins, elastomers, drop-in jet or diesel fuel, and other chemicals is a promising solution. A high temperature fermentation process could decrease energy costs, capital cost, give higher butanol production, and allow for continuous fermentation. In this paper, we describe our approach to genetically transform Geobacillus caldoxylosiliticus, using a pUCG18 plasmid, for potential insertion of a butanol production pathway. Transformation methods tested were electroporation of electrocompetent cells, ternary conjugation with E. coli donor and helper strains, and protoplast fusion. These methods have not been successful using the current plasmid. Growth controls show cells survive the various methods tested, suggesting the possibility of transformation inhibition from a DNA restriction modification system in G. caldoxylosiliticus, as reported in the literature.

\section{Introduction}

Geobacillus bacteria are rod-shaped, aerobic or facultative anaerobic, endospore-forming microbes. Depending on the strain, the temperature range for growth can extend as low as $35^{\circ} \mathrm{C}$ or as high as 80 ${ }^{\circ} \mathrm{C}$, but typically isolates grow between 45 and $70{ }^{\circ} \mathrm{C}$ (Nazina et al. 2001). These characteristics make Geobacillus bacteria attractive as platforms for biofuel production (Cripps 2009, Taylor 2008). These bacteria have been isolated from sources on all seven continents as well as the Pacific Ocean and the Mediterranean Sea. The most frequently reported natural sources for Geobacillus isolates have been hot springs. Most Geobacillus isolates are equipped with a number of sensors, transporters and hydrolytic enzymes specifically adapted to extract energy and metabolic building blocks from plant biomass (Zeigler 2014). Efficient transformation methods for various strains of Geobacillus have previously been established through conjugative transfer (Suzuki 2012), electroporation (Cripps 2009), and protoplast fusion (Zeigler 2001). An advantage of using a thermophilic organism for genetic engineering is the possibility of utilizing temperature as a way to modulate and balance both the engineered pathway and the host's metabolism (Keller 2015).Using renewable biomass like switchgrass and corn stover and converting it into cost-competitive high-performance biofuels and bioproducts is important for the US long-term energy needs. The production of butanol through microbial fermentation and conversion to polyolefins, elastomers, drop-in jet or diesel fuel, and other chemicals is a promising solution for alternative energy.

Clostridia are currently the most studied and industrially used butanol fermenters (Lee et al. 2008), but they have limitations. Clostridia have a low tolerance for butanol, they grow slowly and at ambient temperatures, they require batch production, and they give low product yields, creating high product recovery cost since the product is so dilute (Vane 2008, Weber et al. 2010). One of the most effective ways of effectively harvesting butanol from fermentation is gas stripping, however gas stripping at lower temperatures requires higher gas flow rates, which causes the cost of recovery to increase. When conducted at high temperatures, the efficiency of gas stripping is directly related to vapor pressure of 
the gas. It has been shown that raising the temperature from 25 to $55^{\circ} \mathrm{C}$ can increase butanol recovery from $46 \%$ to $86 \%$ at the same gas flow rate, thus lowering the cost of product recovery (Ollivier et al. 2011).

Developing and demonstrating a high temperature simultaneous saccharification and butanol fermentation system will provide many benefits. Thermophilic conditions will lead to faster hydrolysis rates during the saccharification step of biomass, which can lead to maximized butanol production. It can decrease the energy costs of reactor cooling and also decrease the capitol cost of reactor design. At high temperatures there could be a decrease in reactor contamination, which would help lower the cost of maintaining a sterile environment. High temperatures will also allow more efficient gas stripping of butanol, which would facilitate the use of continuous fermentation. Continuous fermentation would improve the economics of the process by drastically reducing sterilization and reinoculation times, reducing separation costs, and reducing butanol toxicity to the microorganisms (Kumar 2011, Ezeji 2007).

\section{Methods}

\section{Strains}

Geobacillus caldoxylosilyticus ATCC 700356 (ATCC, Manassas, VA, USA), Geobacillus caldoxyloliticus NCIMB 14283 (NCIMB, Bucksburn, Aberdeen, UK), Bacillus licheniformans GBL 2635, Ureibacillus thermophaericus GBL 2643, and Ureibacillus thermophaericus GBL 2666 (Green Biologics Ltd, Milton, Abingdon, United Kingdom) potential butanol-tolerant/butanol-producing bacterial strains were either purchased or provided to the Idaho National Lab. Escherichia coli strains C2925 and NEB 10B were purchased from New England Biolabs (Ipswich, Massachusetts, USA) and used for general preparation of plasmid DNA using the Qiagen miniprep kits. DNA prepared from the C2925 strain is unmethylated DNA, with respect to dam and $d c m$ methylation genes from E. coli. E. coli strain HB101/pRK2013 was purchased from ATCC and used as a helper strain for plasmid transfer during ternary conjugation experiments.

Geobacillus strains were screened for their ability to convert both glucose and xylose into butanol. The strains were grown aerobically on $2 \mathrm{YT}$ ( $16 \mathrm{~g}$ tryptone, $10 \mathrm{~g}$ yeast extract, $5 \mathrm{~g}$ sodium chloride, $1 \mathrm{~L} \mathrm{H}_{2} \mathrm{O}$ ) then transferred to an optical density at $600 \mathrm{~nm}\left(\mathrm{OD}_{600}\right)$ of 0.5 for growth anaerobically on $2 \mathrm{YT}$ plus $0.25 \%$ glucose and $0.5 \%$ xylose. Cell growth rates were determined by $\mathrm{OD}_{600}$ and quantification of butanol was performed by gas chromatography and mass spectrometry using a standard curve.

To establish a protocol for insertion of a butanol pathway for increased butanol production in $G$. caldoxylosilyticus, various transformation methods were tested including electroporation of electrocompetent cells, ternary conjugation, and protoplast transformation. The Geobacillus shuttle vector pUCG18 (Bacillus Genetic Stock Center, Columbus, OH, USA) has a thermostable selectable marker gene conferring kanamycin resistance in E. coli at $37^{\circ} \mathrm{C}$ and in Geobacillus up to $68^{\circ} \mathrm{C}$ (Figure 1). Plasmid DNA was prepared for transformation from $E$. coli strains that are wild type as well as mutated with respect to dam and $\mathrm{dcm}$ methylation genes (Taylor 2008). 


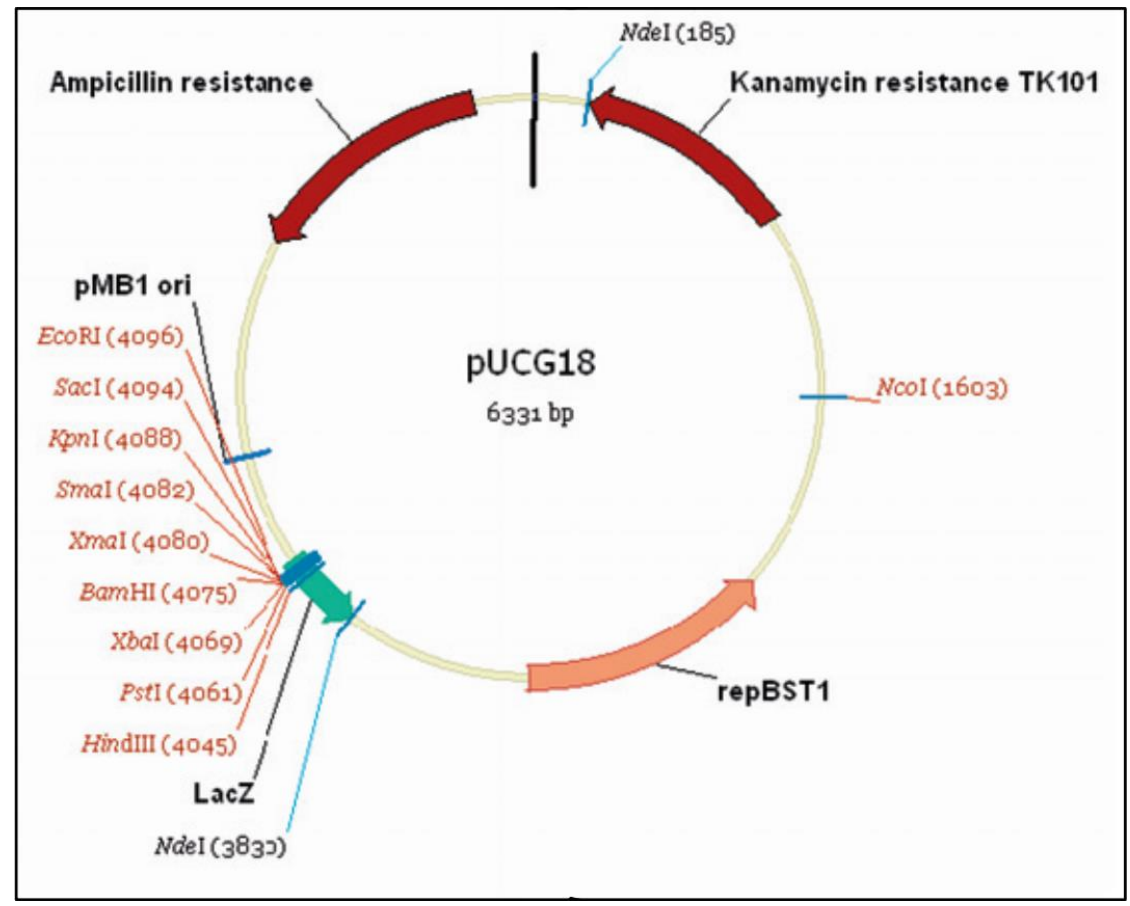

Figure 1. pUCG18 plasmid map (Taylor 2008).

\section{Electroporation of Electrocompetent Cells}

G. caldoxylosilyticus cells were revived by streaking directly from the frozen stock onto a Tryptose Blood Agar Base (TBAB) plates ( $10 \mathrm{~g}$ tryptose, $3 \mathrm{~g}$ beef, $5 \mathrm{~g} \mathrm{NaCl}, 15 \mathrm{~g}$ agar, $1 \mathrm{~L} \mathrm{H}_{2} \mathrm{O}$ ) and incubating overnight at $60^{\circ} \mathrm{C}$. Four or five colonies were picked and grown overnight in $30 \mathrm{~mL}$ of $2 \mathrm{YT}$ at $60^{\circ} \mathrm{C}$ in a shaking incubator set to $220 \mathrm{rpm}$. The cells were subcultured into a baffled flask with $200 \mathrm{~mL}$ of $2 \mathrm{YT}$, at an $\mathrm{OD}_{600}$ of 0.2 until an $\mathrm{OD}_{600}$ of 1.4 was reached. Cultures were cooled on ice for $10 \mathrm{~min}$ and centrifuged at 3,400 $\mathrm{x} \mathrm{g}$ for $20 \mathrm{~min}$ at $4^{\circ} \mathrm{C}$. The cells were resuspended in ice-cold electroporation media $(91 \mathrm{~g}$ mannitol, $91 \mathrm{~g}$ sorbitol, and $10 \%$ glycerol $(\mathrm{v} / \mathrm{v})$ ) and washed 3 times before being resuspended in electroporation media at $2 \%$ of the original volume. Cells were transferred to ice-cold microcentrifuge tubes in $50 \mu \mathrm{L}$ aliquots and mixed with 1-5 $\mu \mathrm{L}$ of pUCG18 plasmid (methylated and unmethylated). Cells were cooled for $5 \mathrm{~min}$ on ice then transferred to an ice-cold $0.1 \mathrm{~cm}$ BioRad electroporation cuvette. An exponential decay program for the BioRad GenePulser II was used with the capacitance range of 10-25 $\mu \mathrm{F}$, voltage range $1500-2500 \mathrm{~V}$, and the pulse controller set to $600 \Omega$. After the pulse was delivered, cells were immediately mixed with $0.5 \mathrm{~mL}$ of $2 \mathrm{YT}$ and allowed to recover for 4 hours at $60^{\circ} \mathrm{C}$ in a shaking incubator set to $220 \mathrm{rpm}$. The cultures were centrifuged at 1,800 x g for $2 \mathrm{~min}$ and cell pellets were resuspended in $100 \mu \mathrm{L}$ of $2 \mathrm{YT}$ then plated on TBAB plates supplemented with kanamycin at $4 \mu \mathrm{g} / \mathrm{mL}$. Plates were incubated at $60^{\circ} \mathrm{C}$ for $24-48$ hours.

\section{Ternary Conjugation with E. coli}

Cells were revived by streaking directly from the frozen stock onto the appropriate agar. E. coli strains C2925 (dam/ $\mathrm{dcm}^{-}$) and HB101/pRK2013 were grown on LB agar plates (10 g NaCl, $10 \mathrm{~g}$ tryptone, $5 \mathrm{~g}$ yeast extract, $15 \mathrm{~g}$ agar (for plates), $1 \mathrm{~L} \mathrm{H}_{2} \mathrm{O}$ ) supplemented with kanamycin at $40 \mu \mathrm{g} / \mu \mathrm{L}$ and incubated overnight at $37^{\circ} \mathrm{C}$. G. caldoxylosilyticus was grown on TBAB and incubated overnight at $60^{\circ} \mathrm{C}$. Four or five colonies were picked from each strain and grown overnight; $\mathrm{E}$. coli at $37^{\circ} \mathrm{C}$ in $30 \mathrm{~mL}$ of LB supplemented with kanamycin at $40 \mu \mathrm{g} / \mathrm{mL}$ and G. caldoxylosilyticus in $30 \mathrm{~mL}$ of $2 \mathrm{YT}$ at $60^{\circ} \mathrm{C}$ in a shaking incubators at 
$220 \mathrm{rpm}$. E. coli strains were subcultured into $20 \mathrm{~mL}$ of LB with antibiotic at a starting $\mathrm{OD}_{600}$ of 0.1 and $G$. caldoxylosilyticus was subcultured into $100 \mathrm{~mL}$ of $2 \mathrm{YT}$ at a starting $\mathrm{OD}_{600}$ of 0.1. Cells were incubated until an $\mathrm{OD}_{600}$ between 0.3 and 0.6. A $10 \mathrm{~mL}$ aliquot of the E. coli $\mathrm{C} 2925$ (with pUCG18) donor strain and the HB101/pRK2013 helper strain were centrifuged together at 3,400 $\mathrm{g}$ for $20 \mathrm{~min}$. The supernatant was discarded and cells were washed and resuspended in LB media a total of 3 times. Similarly, $80 \mathrm{~mL}$ of G. caldoxylosilyticus was pelleted and washed 3 times. After the third centrifugation, cells were resuspended in $1 \mathrm{~mL}$ of $L B$ and all three strains were combined in an 8:1:1 ratio into the same centrifuge tube and centrifuged at 3,400 $\mathrm{g}$ for $20 \mathrm{~min}$. The pellet was placed in the middle of an LB plate and incubated at $37^{\circ} \mathrm{C}$ for $6-16$ hours, after which the pellet was resuspended in $2 \mathrm{~mL}$ of LB and plated on LB supplemented with kanamycin at $4 \mu \mathrm{g} / \mathrm{mL}$ and grown at $60^{\circ} \mathrm{C}$ for $24-48$ hours.

Protoplast Fusion (Zeigler 2001)

G. caldoxylosilyticus was streaked on an mLB agar plate (10 g tryptone, $5 \mathrm{~g}$ yeast extract, $5 \mathrm{~g} \mathrm{NaCl}, 15 \mathrm{~g}$ agar (for plates), $1.25 \mathrm{~mL} 10 \%(\mathrm{w} / \mathrm{v}) \mathrm{NaOH}$ per liter) and grown at $60^{\circ} \mathrm{C}$ overnight. Four or five colonies from the fresh plate were grown in $30 \mathrm{~mL}$ of $\mathrm{mLB}$ at $60^{\circ} \mathrm{C}$ in a shaking incubator set to $220 \mathrm{rpm}$ overnight. G. caldoxylosilyticus was subcultured into $20 \mathrm{~mL}$ of $\mathrm{mLB}$ to give a starting $\mathrm{OD}_{600}$ of $0.3-0.5$. The culture was grown at $60^{\circ} \mathrm{C}$ in a shaking incubator set to $220 \mathrm{rpm}$ until late exponential phase, an $\mathrm{OD}_{600}$ around 0.8-1.0. The culture was centrifuged at 1800-1900 $\times \mathrm{g}$ for $5 \mathrm{~min}$ at room temperature. The pellet was resuspended in $4 \mathrm{~mL}$ of protoplasting media (mLB supplemented with 10\% (w/v) lactose and $10 \mathrm{mM}$ $\mathrm{MgCl}_{2}$ ). Lysozyme was added to $10 \mu \mathrm{g} / \mathrm{mL}$ by adding $40 \mu \mathrm{l}$ of a $1 \mathrm{mg} / \mathrm{mL}$ lysozyme suspension in protoplasting media. Cells were incubated in a shaking water bath at $50^{\circ} \mathrm{C}$ and $130 \mathrm{rpm}$ for $10 \mathrm{~min}$. Protoplasts were diluted by adding $5 \mathrm{~mL}$ protoplasting media, and then gently pelleted by centrifuging at $700-800 \times \mathrm{g}$ for $7 \mathrm{~min}$ at room temperature. The pellet was suspended in $2 \mathrm{~mL}$ of protoplasting media and $0.1 \mathrm{~mL}$ of this protoplast suspension was mixed with 5-20 $\mu$ l of pUCG18 plasmid DNA (methylated or unmethylated) and $0.9 \mathrm{~mL}$ of freshly prepared $40 \%$ (w/v) PEG 600 or PEG 10,000, prepared in protoplasting media. The culture was incubated in a shaking water bath at $50^{\circ} \mathrm{C}$ and $130 \mathrm{rpm}$ for $2 \mathrm{~min}$. The transformation mix was diluted with $2.5 \mathrm{~mL}$ of protoplasting media, and then pelleted by centrifugation at $700-800 \times \mathrm{g}$ for $7 \mathrm{~min}$ at room temperature. The pellet was resuspended in $0.1 \mathrm{~mL}$ of protoplasting media. The culture was incubated in shaking water bath at $50^{\circ} \mathrm{C}$ and $130 \mathrm{rpm}$ for $1 \mathrm{~h}$. A serial dilution of the culture was performed up to $1 \times 10^{-5}$. Dilutions of $1 \times 10^{-3}, 1 \times 10^{-4}$, and $1 \times 10^{-5}$ were plated onto regeneration plates (protoplasting media supplemented with $20 \mathrm{mM} \mathrm{CaCl}_{2}$ and $1 \%$ agar) supplemented with kanamycin at $4 \mu \mathrm{g} / \mu \mathrm{L}$ and grown at $50^{\circ} \mathrm{C}$ for 12 hours, then at $60^{\circ} \mathrm{C}$ for $24-48$ hours until colony formation. Once there was formation, colonies were immediately transferred to TBAB plates supplemented with kanamycin at $4 \mu \mathrm{g} / \mathrm{mL}$ and grown at $60^{\circ} \mathrm{C}$ for $24-48$ hours to help reduce the loss of cell viability.

\section{Results}

\section{Electroporation of Electrocompetent Cells}

Settings were adjusted to give a 5-6 millisecond pulse decay time which allows for optimal efficiency, as reported in the literature. Growth of the controls showed that the cells are able to withstand the shock 
and still be viable after recovery. Freshly prepared electrocompetent cells and electrocompetent cells from a frozen stock have been tested in the electroporation protocol to transform the plasmid.

Ternary Conjugation with E. coli

In an attempt to optimize growth of the Geobacillus bacteria, cells were plated without diluting. A ratio of Geobacillus: E. coli donor: E. coli helper cells of 8:1:1 was used to avoid overgrowth of the $E$. coli strains, as previously reported in the literature.

\section{Protoplast Fusion}

G. caldoxylosilyticus was previously shown to be inhibited at $4 \mu \mathrm{g} / \mathrm{mL}$ on LB plates, but on the regeneration plates there was no inhibition. The lack of complete inhibition allowed cells without the plasmid, thus without the kanamycin selectable marker, to grow. When colonies were transferred to TBAB plates supplemented with kanamycin at $4 \mu \mathrm{g} / \mu \mathrm{L}$, cells would die due to lack of the plasmid. Different concentrations of kanamycin were screened for inhibition and $G$. caldoxylosilyticus grew up to $55 \mu \mathrm{g} / \mu \mathrm{L}$ when added to the TBAB plates.

\section{Butanol Production}

None of the provided strains produced any significant levels of butanol above the background of the no growth control (media only), as shown in Figure 2.

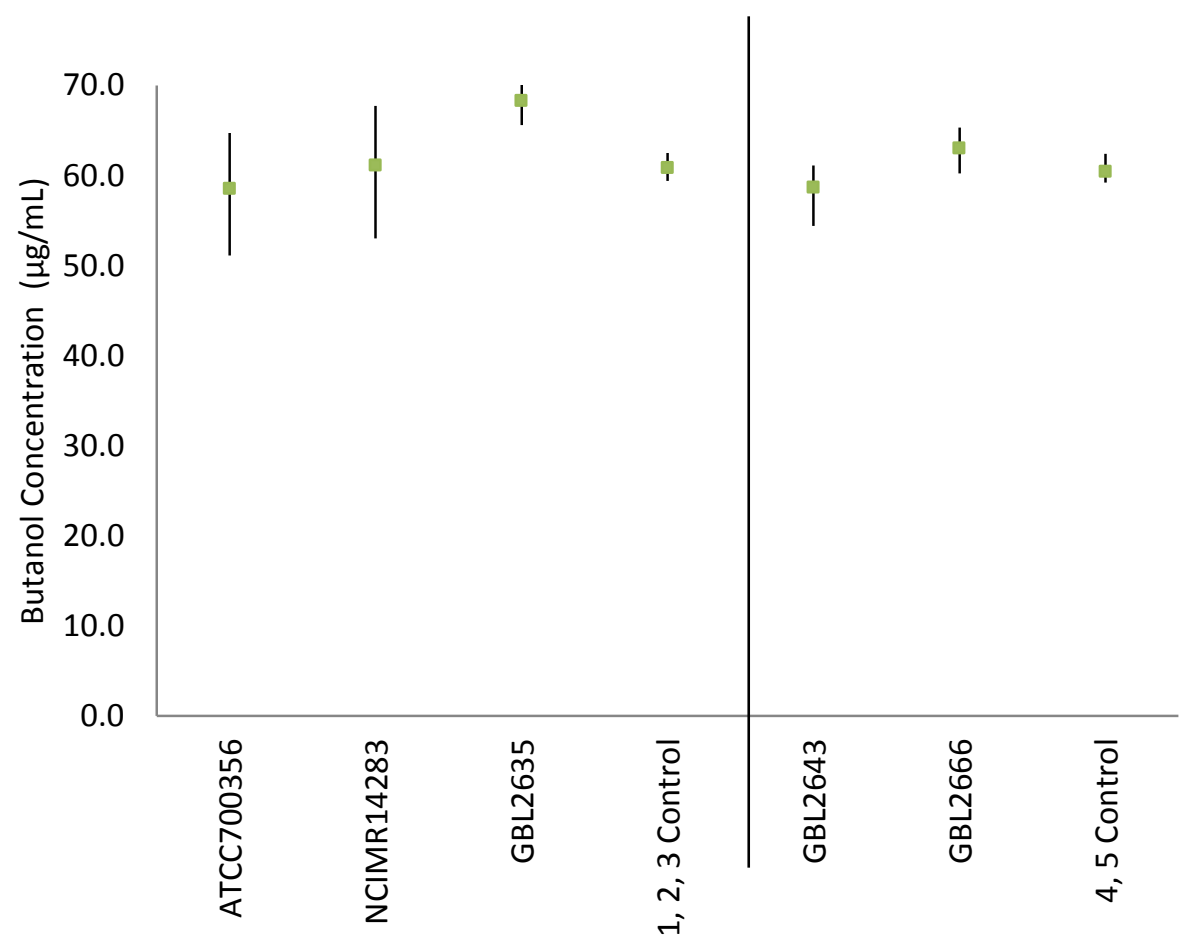

Figure 2. The concentration of butanol produced from Geobacillus caldoxylosiliticus (ATCC700356), Geobacillus caldoxyloliticus TK4 (NCIMB14283), Bacillus licheniformans (GBL2635), Ureibacillus thermophaericus (GBL2643), Ureibacillus thermophaericus (GBL2666) grown on 2YT media with xylose compared to a no growth control (media only control). 
Geobacillus caldoxylosilyticus was the strain selected for further development based on the genetic analysis for butanol homologs and its ability to grow well on xylose. The experimental conditions for electroporation are shown in Table 1. The experimental conditions for ternary conjugation are shown in Table 2.

Table 1. Electroporation conditions tested for electrocompetent cells.

\begin{tabular}{|c|c|c|}
\hline Electroporation run conditions $^{a}$ & Pulse Time (ms) & Growth \\
\hline \multicolumn{3}{|l|}{ E1 } \\
\hline $\mathrm{E} 1,1 \mu \mathrm{l}, 2.5 \mu \mathrm{l}, 5 \mu \mathrm{l}$ of P1, RTRM, R1 & $14.8-15.1$ & No \\
\hline $\mathrm{E} 1,1 \mu \mathrm{l}, 2.5 \mu \mathrm{l}, 5 \mu \mathrm{l}$ of P2, RTRM, R1 & 14.8-15.1 & No \\
\hline $\mathrm{E} 1,1 \mu \mathrm{l}, 2.5 \mu \mathrm{l}, 5 \mu \mathrm{l}$ of $\mathrm{P} 2, \mathrm{ICRM}, \mathrm{R} 1$ & 14.8-15.1 & No \\
\hline $\mathrm{E} 1,1 \mu \mathrm{l}, 2.5 \mu \mathrm{l}, 5 \mu \mathrm{l}$ of $\mathrm{P} 1, \mathrm{ICRM}, \mathrm{R} 2$ & $14.8-15.1$ & No \\
\hline $\mathrm{E} 1,1 \mu \mathrm{l}, 2.5 \mu \mathrm{l}, 5 \mu \mathrm{l}$ of $\mathrm{P} 2, \mathrm{ICRM}, \mathrm{R} 2$ & $14.8-15.1$ & No \\
\hline \multicolumn{3}{|l|}{ E2 } \\
\hline $\mathrm{E} 2,1 \mu \mathrm{l}, 2.5 \mu \mathrm{l}, 5 \mu \mathrm{l}$ of $\mathrm{P} 1, \mathrm{RTRM}, \mathrm{R} 1$ & 14.8-15.1 & No \\
\hline $\mathrm{E} 2,1 \mu \mathrm{l}, 2.5 \mu \mathrm{l}, 5 \mu \mathrm{l}$ of $\mathrm{P} 2, \mathrm{RTRM}, \mathrm{R} 1$ & $14.8-15.1$ & No \\
\hline $\mathrm{E} 2,1 \mu \mathrm{l}, 2.5 \mu \mathrm{l}, 5 \mu \mathrm{l}$ of $\mathrm{P} 1, \mathrm{ICRM}, \mathrm{R} 1$ & 14.8-15.1 & No \\
\hline $\mathrm{E} 2,1 \mu \mathrm{l}, 2.5 \mu \mathrm{l}, 5 \mu \mathrm{l}$ of $\mathrm{P} 2, \mathrm{ICRM}, \mathrm{R} 1$ & $14.8-15.1$ & No \\
\hline $\mathrm{E} 2,1 \mu \mathrm{l}, 2.5 \mu \mathrm{l}, 5 \mu \mathrm{l}$ of $\mathrm{P} 1, \mathrm{ICRM}, \mathrm{R} 2$ & $14.8-15.1$ & No \\
\hline $\mathrm{E} 2,1 \mu \mathrm{l}, 2.5 \mu \mathrm{l}, 5 \mu \mathrm{l}$ of $\mathrm{P} 2, \mathrm{ICRM}, \mathrm{R} 2$ & $14.8-15.1$ & No \\
\hline \multicolumn{3}{|l|}{ E3 } \\
\hline $\mathrm{E} 3,1 \mu \mathrm{l}, 2.5 \mu \mathrm{l}, 5 \mu \mathrm{l}$ of P1, ICRM, R3 & $15.0-15.2$ & No \\
\hline $\mathrm{E} 3,1 \mu \mathrm{l}, 2.5 \mu \mathrm{l}, 5 \mu \mathrm{l}$ of $\mathrm{P} 2, \mathrm{ICRM}, \mathrm{R} 3$ & $15.0-15.2$ & No \\
\hline \multicolumn{3}{|l|}{ E4 } \\
\hline $\mathrm{E} 4,1 \mu \mathrm{l}, 2.5 \mu \mathrm{l}, 5 \mu \mathrm{l}$ of P1, RTRM, R3 & $5.9-6.1$ & No \\
\hline $\mathrm{E} 4,1 \mu \mathrm{l}, 2.5 \mu \mathrm{l}, 5 \mu \mathrm{l}$ of $\mathrm{P} 2, \mathrm{RTRM}, \mathrm{R} 3$ & $5.9-6.1$ & No \\
\hline $\mathrm{E} 4,1 \mu \mathrm{l}, 2.5 \mu \mathrm{l}, 5 \mu \mathrm{l}$ of $\mathrm{P} 1, \mathrm{ICRM}, \mathrm{R} 3$ & $5.9-6.1$ & No \\
\hline $\mathrm{E} 4,1 \mu \mathrm{l}, 2.5 \mu \mathrm{l}, 5 \mu \mathrm{l}$ of $\mathrm{P} 2, \mathrm{ICRM}, \mathrm{R} 3$ & 5.9-6.1 & No \\
\hline $\mathrm{E} 4,1 \mu \mathrm{l}, 2.5 \mu \mathrm{l}, 5 \mu \mathrm{l}$ of $\mathrm{P} 1,55 \mathrm{RM}, \mathrm{R} 3$ & $5.9-6.1$ & No \\
\hline $\mathrm{E} 4,1 \mu \mathrm{l}, 2.5 \mu \mathrm{l}, 5 \mu \mathrm{l}$ of $\mathrm{P} 2,55 \mathrm{RM}, \mathrm{R} 3$ & $5.9-6.1$ & No \\
\hline \multicolumn{3}{|c|}{$\begin{array}{l}\text { E1 denotes } 2500 \mathrm{~V}, 25 \mathrm{uF}, 600 \Omega \text {. E2 denotes } 1500 \mathrm{~V}, 25 \mathrm{uF}, 600 \Omega \text {. E3 denotes } 2000 \mathrm{~V}, 25 \mathrm{uF}, 600 \Omega \text {. E4 denotes } 2000 \mathrm{~V} \text {, } \\
\text { 10uF, } 600 \Omega \text {. P1 denotes pUCG18 met }{ }^{+} . \text {P2 denotes pUCG18 met. RTRM denoted room temperature recovery } \\
\text { media. ICRM denotes ice-cold recovery media. } 55 \mathrm{RM} \text { denotes } 55^{\circ} \mathrm{C} \text { recovery media. R1 denotes } 55^{\circ} \mathrm{C}, 220 \mathrm{rpm}, 16 \\
\text { hours. R2 denotes } 40{ }^{\circ} \mathrm{C}, 0 \mathrm{rpm}, 4 \text { hours. R3 denotes } 50^{\circ} \mathrm{C}, 220 \mathrm{rpm}, 2 \text { hours. }\end{array}$} \\
\hline Starting $O D_{600}$ & Incubation (hours) & Growth \\
\hline $2: 1: 1$ & 12 & No \\
\hline $8: 1: 1$ & 12 & No \\
\hline $8: 1: 1$ & 6 & No \\
\hline $8: 1: 1$ & 12 & No \\
\hline $8: 1: 1$ & 16 & No \\
\hline
\end{tabular}

The ratio was Geobacillus caldoxylosilyticus:dam $/ \mathrm{dcm}^{-}$E. Coli:HB101 


\section{Discussion}

To date there have been no successful transformations of G. caldoxylosilyticus using the pUCG18 plasmid and testing the 3 transformation methods discussed.

G. caldoxylosilyticus was chosen for testing based on certain characteristics desired for potential butanol production. First, it has the ability to grow anaerobically on xylose and glucose at temperatures between 43 and $75^{\circ} \mathrm{C}$, with optimal growth at $65^{\circ} \mathrm{C}$. Literature reports that the enzymatic activities, xylose isomerase and xylulokinase were produced at high levels when grown on glucose, suggesting simultaneous consumption of xylose and glucose; a desired characteristic for efficient simultaneous saccharification. G. caldoxylosilyticus also has the ability to grow anaerobically on the substrates cellobiose, starch, and xylan. It was reported that alcohol dehydrogenase activity was detected when grown anaerobically, suggesting the possibility low ethanol production. Protein sequence homology searches revealed glycosyl hydrolase enzyme homologs for beta-xylosidase and alpha-Larabinofuranosidase may be present in the genome of $G$. caldoxylosilyticus; these enzymes play a role in the deconstruction of xylan (Figure 3). G. caldoxylosilyticus genome sequence also has an annotated $\mathrm{Crt}$ gene coding for the 3-hydroxybutyryl-CoA, suggesting a butanol pathway or part of a pathway may be present (Figure 3).

The Bacillus Genetic Stock Center catalog was consulted for media recipes and protocols, suggesting TBAB media as the best general-purpose solid media for Geobacillus. Each strain formed large, regular colonies on TBAB (Zeigler 2001).

A smaller plasmid pUCG3.8 was synthetically derived by an academic group in the UK and was recently obtained to replace the larger pUCG18. The pUCG3.8 was derived from pUCG18 so it contains all essential genes needed, but the smaller size could help increase the efficiency of the transformation, as reported by Leak, et al. All the transformation methods reported above will be attempted using the smaller pUCG3.8 plasmid (Bartosiak-Jentys 2013). Limited research has been done on $G$.

caldoxylosilyticus so there could also be a restriction modification system that is preventing a successful transformation with the pUCG18 plasmid and may even inhibit the pUCG3.8 plasmid. 


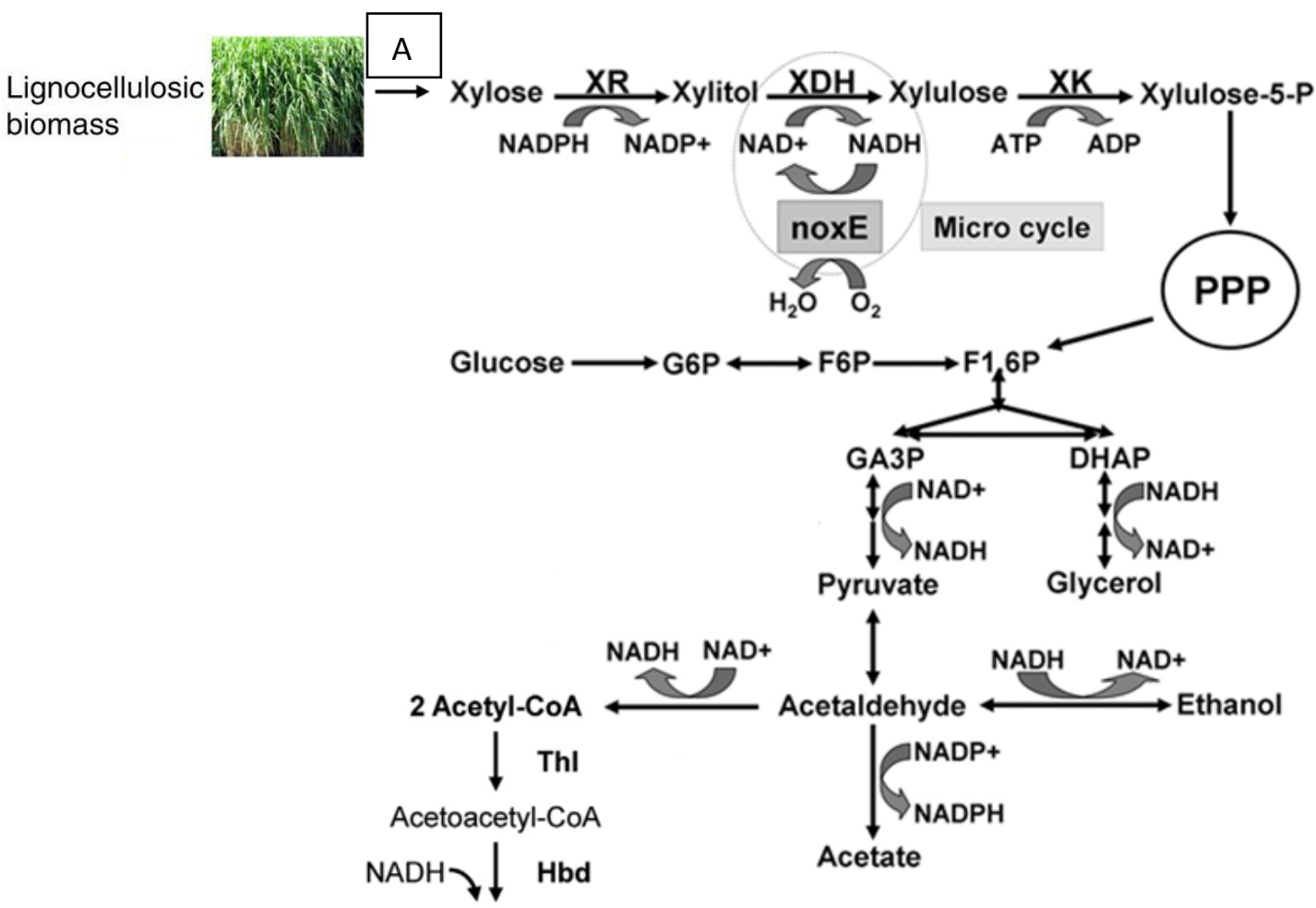

(S)-3-hydroxybutyryl-CoA

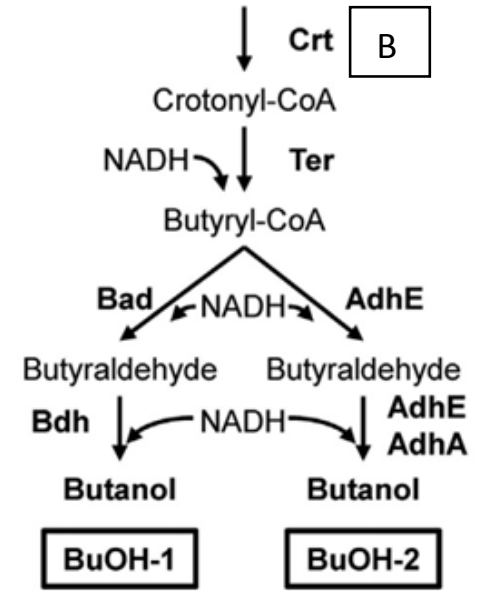

Figure 3. The production pathway of butanol from xylan to the central metabolite acetyl-coA and the enzymes needed to convert acetyl-CoA to butanol. Box $A$ is the process where glycosyl hydrolase enzymes convert xylan to xylose. Box $B$ is the enzyme 3-hydroxybutyryl-CoA, the committed step for butanol production. 


\section{References}

Bartosiak-Jentys J, Hussein AH, Lewis Cl, Leak DJ. 2013. Modular system for assessment of glycosyl hydrolase secretion in Geobacillus thermoglucosidasius. Microbiology. 159. 1267-1275

Cripps RE, Eley K, Leak DJ, Rudd B, Taylor MP, Todd M, Boakes S, Martin S, Atkinson T. 2009. Metabolic engineering of Geobacillus thermoglucosidasius for high yield ethanol production. Metabolic Engineering 11: 398-408.

Ezeji TC, Qureshi N, Blaschek HP. 2003. Production of acetone, butanol and ethanol by Clostridium beijerinckii BA101 and in situ recovery by gas stripping. World J. Micro. Biotech., 19: 595-603.

Keller MW, Lipscomb GL, Loder AJ, Schut GJ, Kelly RM, Adams MW. 2015. A hybrid synthetic pathway for butanol production by a hyperthermophilic microbe. Metabolic Engineering. 27:101-106

Kumar M, Gayen K. 2011. Developments in biobutanol production: New insights. Appl. Energy, 88: 19992012.

Lee SY, Park JH, Jang SH, Nielsen LK, Kim J, Jung KS. 2008. Fermentative butanol production by clostridia. Biotechnol Bioeng. 101: 209-228.

Nazina TN, Tourova TP, Poltaraus AB, Novikova EV, Grigoryan AA, Osipov GA. 2001. Taxonomic study of aerobic thermophilic bacilli: descriptions of Geobacillus subterraneus and Geobacillus uzenensis from petroleum reservoirs and transfer of Bacillus stearothermophilus, Bacillus thermocatenulatus, Bacillus thermoleovorans, Bacillus kaustophilus and Bacillus thermodenitrificans to Geobacillus as the new combinations G. stearothermophilus, G. thermocatenulatus, G. thermoleovorans, G. kaustophilus, G. thermoglucosidasius and G. thermodenitrificans. Int J Syst Evol Microbiol. 51: 433-446.

Ollivier F, Rousseaux R, Cellier C. 2011. Improved gas stripping process for the recovery of solvents from fermentation broths. PCT application WO 2011/003962 A2.

Suzuki H, Ken-ichi Y. 2012. Genetic Transformation of Geobacillus kaustophilus HTA426 by Conjugative Transfer of Host-Mimicking Plasmids. J. Microbiol Biotechnol. 22: 1279-1287

Taylor MP, Esteban CD, Leak DJ. 2008. Development of a versatile shuttle vector for gene expression in Geobacillus spp. Plasmid 60: 45-52.

Vane LM. 2008 Separation technologies for the recovery and dehydration of alcohols from fermentation broths. Biofuel Bioprod Bioref. 2: 553-588.

Weber C, Farwick A, Benisch F, Brat D, Dietz H, Subtil T, Boles E. 2009. Trends and challenges in the microbial production of lignocellulosic alcohol fuels. Appl Microbiol Biotechnol. 87: 1009-1016.

Zeigler DR. 2001. The Genus Geobacillus Introduction and Strain Catalog. Bacillus Genetic Stock Center. 3: $16-22$. 
Zeigler DR. 2014. The Geobacillus paradox: why is a thermophilic bacterial genus so prevalent on a mesophilic planet?. Microbiology. 160: 1-11. 